\title{
IRAN: \\ SOVIET INTERESTS, \\ US CONCERNS
}

By RALPH A. COSSA

PROLOGUE 5

I HISTORICAL PERSPECTIVE 9

Russian Expansion Before 1800

Nineteenth-Century Russian Expansion

Twentieth-Century Russian and Soviet Penetrations of Iran

Lessons from History

II SOVIET MILITARY POSTURE 26

Improved Command and Control

Force Improvements

Expanded Soviet Presence and Influence

III SOVIET STRATEGIC INTERESTS 40

To Preserve Soviet Security

Military Considerations-Ideological Challenges-Outside Alliances-Instability-The Overall Security Equation

To Gain Geopolitical, Economic, or Strategic Advantage Geopolitical Advantages-Economic Advantages-Strategic Advantages

To Consolidate World Socialism

Risks versus Gains

IV IMPLICATIONS 70

The Soviet Threat

Soviet Objectives and Intentions-The Afghan ModelMost Likely Scenario

Effect of Recent Developments

Withdrawal from Afghanistan-Perestroika, Glasnost, and 'New Thinking"-Soviet-Iranian Rapprochement"Neither East nor West"

The Road Ahead

$V$ TOWARD A US STRATEGY 86

NOTES 93 